Studia nad Autorytaryzmem i Totalitaryzmem 43, nr 3

Wrocław 2021

https://doi.org/10.19195/2300-7249.43.3.1

\author{
JACEK BOROWICZ \\ ORCID:0000-0002-1833-4020 \\ Uniwersytet Wrocławski \\ jacek.borowicz@uwr.edu.pl
}

\title{
Dekonstrukcja wolnego zawodu w systemie totalitarnym na przykładzie regulacji prawnej wykonywania zawodu rzecznika patentowego w Polsce w okresie stalinowskim
}

\author{
Słowa kluczowe: totalitaryzm, wolny zawód, rzecznik patentowy, pracownik państwowy. \\ DECONSTRUCTION OF A FREE PROFESSION IN A TOTALITARIAN SYSTEM \\ ON THE EXAMPLE OF LEGAL REGULATION OF THE PROFESSION \\ OF A PATENT ATTORNEY IN POLAND IN THE STALINIST PERIOD
}

\begin{abstract}
In Poland before the Second World War, the profession of patent attorney was categorised as one of the so-called liberal professions. Its legal status and rules of practice were compared to the solicitor profession. A patent attorney practiced his profession personally, independently, and autonomously. In order to exercise his profession, he ran an independent patent attorney's office. In the second half of the 1940s, with the communists taking power in Poland, a radical transformation of the social, political, economic, and legal system of the state along the lines of Stalin's Soviet Union began. Any social, political, or economic activities characterised by independence and autonomy were thus in axiological contradiction with the ideology of the planned totalitarian state. The Act on the Establishment of the College of Patent Attorneys passed on 20 December 1949 completely abolished the structure of the patent attorney profession as a free profession, exercised in its own name and on its own account. From that moment on, the patent attorney became a civil servant performing their professional activities under strict hierarchical subordination to his superiors. There was no guarantee of their intellectual independence or professional autonomy. The practice of the patent attorney profession was subject to public law. The Patent Attorneys College was in fact another state office. It was organisationally and financially linked to the Patent Office - an administrative body granting legal protection to objects of industrial and commercial property, collecting and making available patent documentation and literature. The president of the Patent Office supervised the
\end{abstract}


Patent Attorneys College. Both the Patent Attorneys College and the Patent Office were supervised by the State Economic Planning Commission. The State Commission for Economic Planning was a kind of super-ministry, tasked with a Soviet-style mission of closely supervising and controlling the entire centralised economy of the Polish state. The chairman of the State Economic Planning Commission also had key powers to influence patent attorneys. It was he who determined the subject of their professional examination, he who appointed a person meeting the statutory requirements to the position of a patent attorney. He could also exempt a candidate for the profession from meeting the requirements as well as appoint the president of the Patent Attorneys College. The Act of 20 December 1949 was repealed with the end of the Stalinist period in Poland. In 1958, the profession of patent attorney was briefly reinstated as a free profession. After that, until the end of the existence of the socialist state called the Polish People's Republic, patent attorneys performed their profession as employees within the meaning of the labour law. It was not until the fall of communism in Poland that the profession of a patent attorney was re-established as a liberal profession under the provisions of the Act on Patent Attorneys of 9 January 1993.

Keywords: totalitarianism, Stalinism, free profession, patent agent, civil servant.

\section{Uwagi wprowadzające}

W niniejszym artykule przeanalizowane zostaną przepisy prawa regulujące wykonywanie zawodu rzecznika patentowego w Polsce w okresie od końca lat czterdziestych do drugiej połowy lat pięćdziesiątych XX wieku. Celem będzie poznanie sposobu, w jaki w systemie totalitarnym, osiągającym w Polsce swoje swoiste apogeum w okresie umownie określanym jako „stalinowski”, dokonano prawnej dekonstrukcji profesji rzecznika patentowego jako zawodu wolnego i wkomponowania go w system scentralizowanej administracji państwowej.

Należy na wstępie podkreślić, że od wielu dziesięcioleci, zarówno w II RP, jak i później, po II wojnie światowej w okresie tak zwanej Polski Ludowej, aż do czasów współczesnych w ustawodawstwie polskim brakowało i nadal brakuje prawnej definicji wolnego zawodu. Ustawodawca nie wprowadził zatem do tej pory jednolitego systemowego pojęcia wolnego zawodu. Nie definiował go także w aktach prawnych regulujących wykonywanie poszczególnych zawodów tradycyjnie kwalifikowanych jako wolne ${ }^{1}$. Konsekwencją braku normatywnego określenia wolnego zawodu było i jest nadal powszechne definiowanie go w doktrynie i orzecznictwie przez ustalenie cech dla niego typowych - czyli takich, których wykrycie daje podstawę do uznania, że w danym przypadku mamy do czynienia $\mathrm{z}$ właśnie $\mathrm{z}$ takim zawodem (podejście typologiczne) ${ }^{2}$. Konsekwencją tego podejścia jest między innymi to, że w ciągu lat poszczególni autorzy

${ }^{1}$ Zob. na ten temat więcej J. Borowicz, Wykonywanie wolnego zawodu $w$ ramach stosunku pracy w prawie polskim, Wrocław 2020, s. $23 \mathrm{n}$.

2 Zob. np. W. Boć, Status prawny notariusza, Wrocław 2010, s. 87; J. Jacyszyn, ,, Wolny zawód” - anachronizm czy istotne pojęcie prawne?, „Przegląd Prawa Handlowego” 2015, nr 11, s. $14-19$. 
proponowali i proponują rozmaite identyfikatory, które mają łącznie charakteryzować wolny zawód. Część z nich się powiela lub zazębia, ale są wśród nich także takie, które się różnią. Ponadto niektóre znajdują oparcie w przepisach prawa, inne zaś mają charakter zwyczajowy ${ }^{3}$. We współczesnej literaturze daje się przy tym wyodrębnić swoisty korpus cech typologicznych wolnego zawodu, do których występowania istnieje względna zgoda. Odnosząc powyższe uwagi do wolnych zawodów regulowanych, należy wskazać, że ustawodawca typowo określa ich przedmiot, wskazując na usługi wchodzące w zakres danego zawodu i przyznając, co do zasady, wyłącznie uprawnionym wykonawcom takiego zawodu prawo ich wykonywania. Ponadto ustawodawca formułuje węższy lub szerszy katalog form organizacyjno-prawnych wykonywania zawodu, ze szczególnym uwzględnieniem możliwości indywidualnego, niezależnego i samodzielnego wykonywania go na własny rachunek. Tak ustanowiony w przepisach prawa wolny zawód charakteryzują w szczególności: 1. wysokie kwalifikacje formalne i umiejętności praktyczne wykonawcy, 2. specjalistyczne, typowo korporacyjne, przygotowanie zawodowe wykonawcy połączone z egzaminem zawodowym, 3. stałe doskonalenie zawodowe wykonawcy, 4. osobiste, samodzielne i niezależne wykonywanie zawodu (bez ingerencji zewnętrznej w tok działań związanych $\mathrm{z}$ wykonywaniem zawodu), 5. szczególne stosunki z odbiorcami usług cechujące się zaufaniem i dyskrecją, co wiąże się z zachowaniem tajemnicy zawodowej, 6. ponoszenie osobistej odpowiedzialności za należyte wykonanie świadczenia (materialnej i korporacyjnej — zawodowej), 7. przestrzeganie zasad deontologicznych, 8. uiszczanie na rzecz wykonawcy honorarium w zasadzie dobrowolnego i swobodnie zaakceptowanego, wykluczającego cel lukratywny, 9. istnienie samorządu zawodowego i obowiązkowa przynależność do niego ${ }^{4}$.

\section{Dwudziestolecie międzywojenne - profesja rzecznika patentowego jako wolny zawód}

Zrozumienie skali zmian $\mathrm{w}$ zakresie statusu prawnego rzeczników patentowych w Polsce pod koniec lat czterdziestych XX wieku wymaga spojrzenia na stan regulacji prawnej tego zawodu w czasie II RP jako tej, która w ujęciu historycznym poprzedzała rozwiązania prawne wprowadzane przez komunistów w Polsce po zakończeniu II wojny światowej. Istniejące wówczas unormowania prawne oceniać można jako stosunkowo ograniczone, a zawód ten i zasady jego wykonywania nie podlegały drobiazgowej prawnej regulacji. Interpretować to można również w kategoriach pozostawiania jego przedstawicielom stosunkowo

3 W. Boć, op. cit., s. 87-88.

${ }^{4}$ Zob. np. ibidem, s. 88-90; J. Jacyszyn, Wolny zawód - mit czy rzeczywistość prawna, „Przegląd Prawa i Administracji” 100, 2015, nr 1, s. 551-552. 
szerokiej autonomii zawodowej przez minimalną reglamentację prawną zasad jego wykonywania. Rozporządzenie Prezydenta Rzeczypospolitej z dnia 22 marca 1928 roku o ochronie wynalazków, wzorów i znaków towarowych ${ }^{5}$, które zastąpiło wcześniejszą ustawę z dnia 5 lutego 1924 roku o ochronie wynalazków, wzorów i znaków towarowych ${ }^{6}$, określało wymogi, jakie spełniać miała osoba aspirująca do wykonywania zawodu rzecznika patentowego. Zgodnie z jego art. 241 ust. 1-3 rzecznikiem mógł zostać tylko obywatel polski, pełnoletni, w Polsce stale zamieszkały, korzystający z pełni praw obywatelskich i posiadający odpowiednie wykształcenie ${ }^{7}$. Rzeczników patentowych mianował Minister Przemysłu i Handlu na wniosek Prezesa Urzędu Patentowego. Należy podkreślić, że dokonania mianowania przez ministra nie można było utożsamiać z nadaniem rzecznikowi statusu urzędnika Urzędu Patentowego (pracownika państwowego). W literaturze przyjmuje się, że nominacja ta potwierdzała jedynie konstytutywny charakter nabytych uprawnień zawodowych, stwarzając możliwość wykonywania wolnego zawodu $^{8}$. Rzeczników po ich mianowaniu i złożeniu przez nich w urzędzie przysięgi podług roty, zatwierdzonej przez Ministra Przemysłu i Handlu w porozumieniu z Ministrem Sprawiedliwości, wpisywano do urzędowej listy rzeczników patentowych, przez co nadawano im prawo do wykonywania czynności zawodowych (art. 240 ust. 1-2 rozporządzenia). Przejawem szczególnego statusu zawodowego rzeczników patentowych w sferze odpowiedzialności z tytułu nieprawidłowego wykonania czynności zawodowych było poddanie ich dyscyplinarnej władzy osobnej „Komisji Dyscyplinarnej przy Urzędzie Patentowym Rzeczypospolitej Polskiej" (art. 243 ust. 1 rozporządzenia). Czy zawód rzecznika patentowego pod rządami wymienionych aktów prawnych zakwalifikować można było do kategorii zawodów uznawanych ówcześnie za wolne? W doktrynie międzywojennej uznawano, że z wolnym zawodem mamy do czynienia, gdy ktoś osobiście i samoistnie, zarobkowo i zawodowo zaspokajał, najczęściej przez świadczenia

5 Dz.U.1928.39.384 z dnia 26 marca $1928 \mathrm{r}$.

6 Dz.U.1924.31.306 z dnia 10 kwietnia 1924 r. Można przyjąć, że przepisy rozporządzenia Prezydenta Rzeczypospolitej z dnia 22 marca 1928 r. o ochronie wynalazków, wzorów i znaków towarowych co do zasady powielały rozwiązania dotyczące zawodu rzecznika patentowego obowiązujące na gruncie przepisów ustawy z dnia 5 lutego 1924 r. o ochronie wynalazków, wzorów i znaków towarowych, zob. jej art. 157-160. Zmiana, która zaszła w przepisach rozporządzenia, polegała na wskazaniu, że rzecznikiem patentowym mogła zostać osoba z wykształceniem prawniczym, spełniająca pewne dodatkowe wymogi określone tym rozporządzeniem.

7 Tę ostatnią przesłankę spełniał ten, kto albo ukończył akademicką szkołę techniczną, mógł się wykazać przynajmniej dwuletnią praktyką w sprawach patentów, wzorów i znaków towarowych, a ponadto złożył przed Urzędem Patentowym egzamin z prawa z wynikiem dostatecznym (przy czym przedmiot egzaminu określało rozporządzenie Ministra Przemysłu i Handlu), albo ukończył wydział prawa na jednym z uniwersytetów w Polsce i złożył egzaminy uniwersyteckie z ukończonych studiów prawniczych lub uzyskał nostryfikację odpowiedniego zagranicznego dyplomu w myśl obowiązujących przepisów oraz przynajmniej przez lat sześć pełnił służbę referendarską w Urzędzie Patentowym Rzeczypospolitej Polskiej.

8 M. Słomski, Historia rzecznictwa patentowego w Polsce, Kraków 1997, s. 51. 
polegające na usługach, potrzeby różnych osób (klientów), chociaż nie posiadał żadnego wyodrębnionego zakładu, z którym klientela byłaby związana i który jako przedsiębiorstwo mógłby być sprzedany lub w postaci spadku pozostawiony spadkobiercom. Do kręgu tak rozumianych wolnych zawodów zaliczono między innymi profesje prawnicze takie, jak adwokaci, notariusze i rzecznicy patentowi ${ }^{9}$. W kontekście tematyki niniejszego opracowania podkreślić należy w szczególności formułowane w ówczesnej literaturze cechy wolnego zawodu, jak osobiste i samoistne spełnienie usługi zawodowej w bezpośredniej relacji z klientem (bez „pośrednictwa”, powiązania z wyodrębnionym zakładem/przedsiębiorstwa). Wykonawca tak ujmowanego wolnego zawodu realizował zatem usługę zawodową w granicach swoich uprawnień zawodowych, działając we własnej osobie i wykorzystując posiadaną wiedzę i doświadczenie zawodowe. Należy szczególnie podkreślić przy tym, że krąg znaczeń językowych przepisywanych działaniom określanym jako „samoistne” obejmował w ówczesnej polszczyźnie tak fundamentalne i zachowujące do dzisiaj aktualność dla charakterystyki wolnego zawodu aspekty, jak działanie ,bez niczyjej pomocy, bez niczyjego wpływu; niezależnie, samodzielnie" ${ }^{10}$. Zawód rzecznika patentowego w II RP zaliczany zatem, podobnie jak zawód adwokata, do kategorii zawodów wolnych wykonywany był przez stosunkowo nielicznych jego przedstawicieli prowadzących wyspecjalizowane indywidualne i rzadziej wspólne kancelarie — podobnie jak adwokaci ${ }^{11}$.

\section{Zawód rzecznika patentowego w okresie stalinowskim}

Fundamentalna zmiana statusu prawnego rzecznika patentowego dokonana została po okresie przejściowego stosowania do roku 1948 rozporządzenia Prezydenta Rzeczypospolitej z dnia 22 marca 1928 roku o ochronie wynalazków, wzorów i znaków towarowych ${ }^{12}$. Ustawa z dnia 20 grudnia 1949 roku o utworzeniu

9 Zob. literatura w J. Jacyszyn, Wykonywanie wolnych zawodów w Polsce, Warszawa 2004, s. 19 n.; oraz K. Wojtczak, Zawód i jego prawna reglamentacja. Studium z zakresu materialnego prawa administracyjnego, Poznań 1999, s. 62, 82.

10 Zob. https://sjp.pwn.pl/doroszewski/samoistnie;5494813.html (dostęp: 13.04.2021). Warto podkreślić, że w słowniku pod red. W. Doroszewskiego przytaczane znaczenie słowa „samoistnie” uznawane jest za przestarzałe — można je więc odnosić zasadnie do okresu sprzed jego ukazaniem się - a więc także praktyki stosowania języka polskiego w okresie przed II wojną światową.

11 J. Borowicz, Status prawny rzecznika patentowego zatrudnionego w ramach stosunku pra$c y$, „Praca i Zabezpieczenie Społeczne” 1994, nr 7, s. 58. Na przykład pod rządami rozporządzenia Prezydenta Rzeczypospolitej z dnia 22 marca 1928 roku o ochronie wynalazków, wzorów i znaków towarowych wpis na listę uzyskał jeden prawnik oraz 19 inżynierów; zob. M. Słomski, op. cit., s. 54-55.

12 Także po próbach zaradzenia brakowi rzeczników patentowych przez wprowadzenie epizodycznych i nieprzynoszących efektów rozwiązań obniżających wymagania zawodowe, w postaci dekretu z 1947 roku o wyjątkowym dopuszczeniu do wykonywania czynności zawodowych rzecznika patentowego, Dz.U.1947.60.330; zob. M. Słomski, op. cit., s. 56-57. 
Kolegium Rzeczników Patentowych ${ }^{13}$ (dalej: u.k.r.p.), wchodząca w życie już 29 grudnia, w całości odchodziła od konstrukcji zawodu rzecznika patentowego jako wolnego, wykonywanego we własnym imieniu i na własny rachunek. Zgodnie $\mathrm{z}$ art. 15 ust. 1 u.k.r.p. $\mathrm{z}$ dniem wejścia $\mathrm{w}$ życie tej ustawy członkowie wspomnianego Kolegium tracili uprawnienia do wykonywania czynności zawodowych we własnym imieniu i na własny rachunek ${ }^{14}$. Na mocy art. 1 ustawy utworzono przy Urzędzie Patentowym Rzeczypospolitej Polskiej Kolegium Rzeczników Patentowych, nad którym nadzór sprawował Prezes Urzędu Patentowego. Kolegium owo powołano do: 1. udzielania osobom zainteresowanym porad i pomocy technicznej i prawnej w sprawach wynalazków, wzorów użytkowych i zdobniczych oraz znaków towarowych, 2. współdziałania z instytucjami państwowymi i społecznymi w dziedzinie popierania twórczości technicznej, a w szczególności do współdziałania z instytucjami naukowo-badawczymi oraz z innymi instytucjami o podobnym charakterze $\mathrm{w}$ zakresie udzielania osobom zainteresowanym porad i pomocy technicznej, 3. zastępowania osób zainteresowanych przed Urzędem Patentowym w sprawach wymienionych w pkt 1 (art. 2 u.k.r.p.). W aspekcie finansowania swojej działalności Kolegium Rzeczników Patentowych powiązane było ściśle z Urzędem Patentowym, jako że jego budżet stanowił odrębny rozdział budżetu Urzędu Patentowego (art. 10 u.k.r.p.). Szczegółową organizację i zakres działania Kolegium określał z kolei Przewodniczący Państwowej Komisji Planowania Gospodarczego (dalej: PKPG) jako podmiot upoważniony do nadania mu statutu w drodze zarządzenia (art. 11 ust. 1-3 u.k.r.p.). Przewodniczący PKPG tworzył również oddziały rejonowe Kolegium (zarządzeniem wydanym na wniosek Prezesa Urzędu Patentowego) oraz - co istotne - mianował na wniosek Prezesa Urzędu Patentowego rzeczników patentowych jako członków Kolegium oraz jego przewodniczącego (art. 4-6 u.k.r.p.).

W zakresie regulacji statusu prawnego rzeczników patentowych ustawa z dnia 20 grudnia 1949 roku o utworzeniu Kolegium Rzeczników Patentowych określała w sposób charakterystyczny dla przepisów dotyczących pracowników państwowych wymogi warunkujące dostęp do tego zawodu. Zgodnie $\mathrm{z}$ art. 7 ust. 1 u.k.r.p. rzecznikiem patentowym mógł być obywatel polski, stale w Polsce zamieszkały, korzystający z pełni praw obywatelskich, który ukończył wyższą szkołę techniczną lub równorzędne studia techniczne i złożył przed komisją w Urzędzie Patentowym

13 Dz.U.1949.63.495 z dnia 29 grudnia 1949 r.

14 Wyjąwszy przypadki, o których mowa była w art. 15 ust. 2 i 3 u.k.r.p. Zgodnie z jego brzmieniem do czasu zorganizowania Kolegium, nie dłużej jednak niż w ciągu trzech miesięcy od dnia wejścia w życie niniejszej ustawy, członkowie Kolegium mogli przyjmować zlecenia oraz pełnomocnictwa bezpośrednio od osób zainteresowanych i wykonywać wszelkie czynności zgodnie z otrzymanymi zleceniami we własnym imieniu i na własny rachunek. Jeżeli jednak rzecznik patentowy nie mógł załatwić w okresie sześciu miesięcy spraw przyjętych przed wejściem w życie niniejszej ustawy oraz wymienionych w art. 15 ust. 2, powinien był zgłosić przewodniczącemu Kolegium wniosek o przedłużenie terminu. 
egzamin na stanowisko rzecznika patentowego, a ponadto: 1. odbył dwuletnią aplikację w Kolegium albo 2. pełnił służbę w Urzędzie Patentowym przez okres dwuletni na stanowisku pracownika jednej ze służb specjalnych, w tym przez okres co najmniej jednoroczny w dziale wynalazków i co najmniej sześciomiesięczny w dziale znaków towarowych oraz odbył trzymiesięczną aplikację w Kolegium, albo 3. wykazał się czteroletnią praktyką w sprawach patentów, wzorów i znaków towarowych i odbył trzymiesięczną aplikację w Kolegium. Z kolei zgodnie z art. 7 ust. 2 u.k.r.p. rzecznikiem patentowym mógł być również obywatel polski, stale w Polsce zamieszkały, korzystający z pełni praw obywatelskich, który: 1. ukończył wydział prawa na jednym z uniwersytetów w Polsce lub uzyskał nostryfikację odpowiedniego zagranicznego dyplomu w myśl obowiązujących przepisów, 2. pełnił służbę w Urzędzie Patentowym na stanowisku pracownika jednej ze służb specjalnych przynajmniej przez okres czteroletni, w tym przez co najmniej dwuletni w dziale wynalazków i co najmniej roczny w dziale znaków towarowych, 3. odbył trzymiesięczną aplikację w Kolegium oraz 4. złożył przed komisją w Urzędzie Patentowym egzamin na stanowisko rzecznika patentowego. Na pokreślenie zasługuje to, że Przewodniczącemu PKPG oprócz uprawnienia do mianowania rzeczników patentowych w zwykłym trybie przypisano także uprawnienie do tego, by „ogólnie lub w przypadkach szczególnie uzasadnionych zwalniać kandydatów na stanowiska rzeczników patentowych, o których mowa w ust. 1, od wszystkich lub niektórych wymagań" określonych w ustawie, oraz uprawnienie do określenia w drodze zarządzenia przedmiotu egzaminu na stanowisko rzecznika patentowego (art. 7 ust. 3-4 u.k.r.p.).

Podkreśla się, że nabycie uprawnień zawodowych pod rządami ustawy z dnia 20 grudnia 1949 roku nie wiązało się ze składaniem przyrzeczeń/przysięg, nie było także zgłaszane ani wpisywane do rejestru urzędowego (listy rzeczników patentowych) $)^{15}$.

Przepisy ustawy z dnia 20 grudnia 1949 roku o utworzeniu Kolegium Rzeczników Patentowych wprowadziły ścisłą reglamentację prawną w zakresie formy wykonywania zawodu rzecznika patentowego. Zawód ten mógł być wykonywany wyłącznie w formule urzędniczej - w charakterze mianowanego pracownika państwowego $\mathrm{w}$ ramach stosunku służbowego (art. 6 i art. 8 u.k.r.p.) ${ }^{16}$. Mimo wprowadzenia stosunkowo rozległej w porównaniu ze stanem prawnym „odziedziczonym" po okresie II RP regulacji dotyczącej statusu prawnego rzeczników patentowych ustawa z 20 grudnia 1949 roku o utworzeniu Kolegium Rzeczników Patentowych nie zawierała odrębnych uregulowań dotyczących ich praw i obowiązków. Aktem prawnym, który zachowywał w tym zakresie aktualność, były

15 M. Słomski, op. cit., s. 59 n.

16 Zgodnie z art. 6 ust. 2. u.k.r.p. w Kolegium zatrudnieni być mieli ponadto mianowani przez Prezesa Urzędu Patentowego na wniosek przewodniczącego Kolegium: 1. aplikanci na stanowiska rzeczników patentowych, 2. pracownicy służb specjalnych, 3. pracownicy służby ogólnej. 
utrzymane w mocy przepisy ustawy z dnia 17 lutego 1922 roku o państwowej służbie cywilnej (dalej: u.p.s.c.) ${ }^{17}$.

Znamienne wydaje się, że w ustawie z dnia 20 grudnia 1949 r. o utworzeniu Kolegium Rzeczników Patentowych brakowało jakichkolwiek przepisów gwarantujących jego niezależność intelektualną w wykonywaniu czynności merytorycznych. Znalazło się natomiast miejsce na przepis, na mocy którego członkowie Kolegium i aplikanci w zakresie naruszenia obowiązków służbowych podlegać mieli komisji dyscyplinarnej, powołanej przez Przewodniczącego Państwowej Komisji Planowania Gospodarczego na wniosek Prezesa Urzędu Patentowego (art. 12 u.k.r.p.).

\section{Status prawny rzeczników patentowych w świetle przepisów ustaw: z dnia 20 grudnia 1949 roku} o utworzeniu Kolegium Rzeczników Patentowych oraz z dnia 17 lutego 1922 roku o państwowej służbie cywilnej — próba oceny

Analiza przedstawionych uregulowań prawnych pozwala stwierdzić, że w systemie totalitarnym kształtującym się w Polsce od połowy lat czterdziestych XX wieku osobista, nacechowana zaufaniem i chroniona tajemnicą zawodową więź między wykonawcą wolnego zawodu rzecznika patentowego a odbiorcą jego usług zawodowych została zastąpiona relacją między petentem a organem administracji państwowej reprezentowanym przez jego urzędnika - rzecznika patentowego, zatrudnionego jako pracownik państwowy w ramach stosunku służbowego. Znamienne jest, że działania i czynności wchodzące do tej pory tradycyjnie do przedmiotu zawodu rzecznika patentowego, objęte przypisanymi mu uprawnieniami zawodowym i realizowane przez niego osobiście i samoistnie przybrały tu formę kompetencji i uprawnień Kolegium Rzeczników Patentowych jako organu administracji powołanego do ich realizacji (art. 2 u.k.r.p.). Rzecznik patentowy stracił swoją podmiotowość i odrębność w sferze zawodowej, nie występując już jako samodzielny podmiot uprawnień zawodowych, mógł wykonywać rzecznikowskie wyłącznie $\mathrm{w}$ imieniu uprawnionego organu administracji państwowej i w jego ramach. Kolegium Rzeczników Patentowych zaś zostało wpisane $\mathrm{w}$ sieć hierarchicznych zależności tworzonych przez scentralizowany system organów państwowych (Kolegium Rzeczników Patentowych - Urząd Patentowy - Państwowa Komisja Planowania Gospodarczego). Pozostawało ostatecznie podporządkowane Państwowej Komisji Planowania Gospodarczego

17 Tekst jedn. Dz.U.1949.11.72 z dnia 11 marca 1949 r. Szczegółowe prawa i obowiązki pracowników państwowych określały rozdziały 2 i 3 u.s.p.c. 
jako swoistemu superministerstwu — organowi administracji państwowej nadrzędnemu wobec ministerstw gospodarczych, którego powołanie uznaje się za istotny przejaw centralizacji zarządzania gospodarką i ograniczania samodzielności podległych szczebli zarządzania i jednostek wykonawczych, między innymi przez wdrażanie sowieckich rozwiązań i instrukcji planistycznych ${ }^{18}$.

Regulacja prawna wymogów warunkujących uzyskanie statusu rzecznika patentowego oraz zasad nabywania uprawnień zawodowych umieszczała wyspecjalizowane procedury tej kwestii dotyczące (aplikacje rzeczniowskie) wewnątrz Kolegium. Uwagę zwracać może wskazanie wśród wymogów alternatywnych wobec pełnowymiarowej aplikacji przypadku wcześniejszego pełnienia kilkuletniej służby w Urzędzie Patentowym na stanowisku pracownika jednej ze „służb specjalnych" w rozumieniu ustawy z dnia 17 lutego 1922 roku o państwowej służbie cywilnej ${ }^{19}$. Oznaczałoby to możliwość uzyskiwania uprawnień zawodowych przez osoby poddane kilkuletniemu okresowi urzędniczego formowania, w pełni przystosowane do funkcjonowania $\mathrm{w}$ warunkach podporządkowania służbowego. Znamienne jest także przypisanie Przewodniczącemu PKPG uprawnienia do mianowania na rzecznika patentowego osób niespełniających kryteriów ustawowych. W systemie totalitarnym istotne było zatem zabezpieczanie wszelkich możliwości kształtowania składu osobowego Kolegium w sposób gwarantujący uległość jego członków wobec rządów obowiązującej opcji politycznej.

Rzecznik patentowy jako pracownik państwowy poddany był „władzy służbowej", realizowanej przez zwierzchnika, który powołany był do sprawowania nad nim bezpośredniego „nadzoru służbowego”. W konsekwencji pod rządami ustawy z dnia 20 grudnia 1949 roku o utworzeniu Kolegium Rzeczników Patentowych oraz utrzymanych w mocy przepisów ustawy z dnia 17 lutego 1922 roku o państwowej służbie cywilnej nie można było mówić o zachowaniu kluczowej dla wyodrębnienia wolnego zawodu niezależności intelektualnej i samodzielności zawodowej rzecznika patentowego w zakresie jego czynności służbowych. Rzecznik patentowy jako pracownik państwowy wykonywać miał swoje obowiązki w ramach ścisłego i wielowymiarowego podporządkowania służbowego. Jego podstawowym wyrazem było ustawowe zobowiązanie do wykonywania

18 https://encyklopedia.pwn.pl/haslo/Panstwowa-Komisja-Planowania-Gospodarczego; 3953970.html (dostęp: 8.04.2021). Szczegółowy zakres działania PKPG określało rozporządzenie Rady Ministrów z dnia 22 kwietnia 1949 r. w sprawie zakresu działania Państwowej Komisji Planowania Gospodarczego (Dz.U.1949.26.190) — zob. § 3.

19 Pojęcie „służby specjalne” rozpatrywane ze współczesnego punktu widzenia może być mylące. Zgodnie z art. 10 u.p.s.c. ze względu na wymagane przygotowanie teoretyczne i praktyczne pracownicy państwowi dzielili się na dwie grupy: a) pracowników służb specjalnych, b) pracowników służby ogólnej. Do służb specjalnych zaliczano te stanowiska, na których pełnienie funkcji przez pracowników państwowych wymagało specjalnego przygotowania teoretycznego i praktycznego. Rada Ministrów ustalała w drodze rozporządzenia, które stanowiska uznawane były za służby specjalne oraz jakie przygotowanie teoretyczne i praktyczne winni mieć byli kandydaci do tych stanowisk. Stanowiska niezaliczone do grup specjalnych należały do grupy służby ogólnej. 
poleceń swoich przełożonych, o ile wyraźnie nie sprzeciwiałyby się one obowiązującym przepisom ustawowym (art. 22 u.p.s.c.). Rzecznikowi można było nakazać także czasowo wykonywanie czynności urzędowych, które nie należały do jego zwykłych obowiązków służbowych (art. 23 u.p.s.c.). Jako pewną namiastkę niezależności rzecznika traktować można ograniczoną procedurę kwestionowania polecenia służbowego, o ile w przekonaniu pracownika państwowego przeciwne byłoby ono dobru służby albo dobru publicznemu w ogólności lub też zawierało znamiona pomyłki co do faktu albo co do prawa ${ }^{20}$.

Podporządkowanie służbowe rzecznika patentowego miało również wymiar organizacyjny. Rzecznik wraz z pozostałymi pracownikami Kolegium pozostawał w stosunkach hierarchicznych, zależnych od stanowisk, na których pełnili oni swoje obowiązki. Nie było zatem mowy o jakiejkolwiek prawem gwarantowanej samodzielności organizacyjnej czy na przykład możliwości samodzielnej organizacji pracy, znanej z współczesnych rozwiązań prawnych w przypadku tych wolnych zawodów, które wykonywane są w ramach stosunku pracy ${ }^{21}$. Swoje obowiązki rzecznik patentowy powinien był wykonywać, przestrzegając przepisanych godzin urzędowych. Ponadto, jeżeli według uznania „władzy” wymagałyby tego ważne względy służbowe - powinien był sprawować swoje czynności także poza przepisanymi godzinami zajęć służbowych (art. 27 u.p.s.c.). Wymiar dyspozycyjności rzecznika patentowego jako pracownika państwowego podkreślał obowiązek informowania „władzy służbowej” o każdej przeszkodzie w pełnieniu służby, wywołanej czy to chorobą, czy innymi uzasadnionymi powodami, oraz udowadniania tych przeszkód, na przykład przez poddanie się badaniom lekarskim (art. 28 u.p.s.c.). Rzecznikowi patentowemu nie wolno było przyjąć żadnej posady i stanowiska ani też oddawać się poza urzędem takim zajęciom, których wykonywanie stałoby w sprzeczności z jego obowiązkami służbowymi, przeszkadzałoby mu w ścisłym wykonywaniu czynności urzędowych lub mogło wywołać uzasadnione podejrzenie o stronniczość lub interesowność (art. 29 u.p.s.c.).

${ }^{20}$ Przepisy art. 22 u.p.s.c. przewidywały procedurę kwestionowania polecenia służbowego, o ile w przekonaniu pracownika państwowego przeciwne byłoby ono dobru służby albo dobru publicznemu w ogólności lub też zawierało znamiona pomyłki co do faktu albo co do prawa. Jednak przepisy stanowiły, że „w wypadkach, gdy zniesienie się z władzą przełożoną pociągnęłoby za sobą niewykonalność lub bezprzedmiotowość zlecenia, nie przeciwnego wyraźnie przepisom obowiązującym — pracownik państwowy obowiązany jest zlecenie to wykonać, wyjąwszy wypadek grożącej stąd niepowetowanej szkody”.

21 Współcześnie co do niektórych wolnych zawodów samodzielność zawodową pracownika zabezpieczają także przepisy określające jego miejsce w strukturze organizacyjnej zakładu pracy. Przykładów dostarczają tu przepisy dotyczące radców prawnych, rzeczników patentowych i doradców podatkowych. Wykonując te zawody w ramach stosunku pracy, pracownicy zajmować mają stanowisko podległe bezpośrednio kierownikowi jednostki organizacyjnej / kierownikowi podmiotu, w którym są zatrudnieni (zob. art. 9 ust. 1 ustawy z dnia 6 lipca 1982 r. o radcach prawnych, tekst jedn. Dz.U.2020.75; art. 4 ust. 4 ustawy z dnia 11 kwietnia 2001 r. o rzecznikach patentowych, tekst jedn. Dz.U.2019.1861 ze zm.; art. 31 ust. 1a ustawy z dnia 5 lipca 1996 r. o doradztwie podatkowym, tekst jedn. Dz.U.2020.130); więcej zob. J. Borowicz, Wykonywanie..., s. 353 n. 
Powinien było on ponadto obrać sobie miejsce zamieszkania w ten sposób, by mógł czynić zadość wszystkim obowiązkom służby, wskazując władzy służbowej miejsce swego pobytu i donosząc o każdej jego zmianie (art. 32 u.p.s.c.).

Podsumowując, w sytuacji prawnej rzecznika patentowego pod rządami wymienionych aktów prawnych znajdowały odzwierciedlenie kluczowe elementy charakteryzujące służbę państwową. Uwagę zwracało w szczególności to, że państwo jednostronnie określało w drodze ustawowej prawa i obowiązki zarówno rzecznika, jak i swoje. Publicznoprawny charakter służby pełnionej przez rzecznika patentowego znajdował wyraz $\mathrm{w}$ administracyjnoprawnym akcie przyjęcia do służby w postaci mianowania. Rzecznik pozostawał w układzie podporządkowania służbowego oraz dyspozycyjności, będąc zobowiązany do wykonywania poleceń przełożonych. Podlegał także rozmaitym ograniczeniom i powinnościom wynikającym ze służby i ustanawianym w jej interesie oraz wzmocnionym rygorom odpowiedzialności za swoje działania jako pracownika państwowego ${ }^{22}$.

Skala dekonstrukcji wolnego zawodu pod rządami ustawy z dnia 20 grudnia 1949 roku o utworzeniu Kolegium Rzeczników Patentowych staje się w pełni widoczna w konfrontacji z rozwiązaniami przyjętymi w ustawie z dnia 22 maja 1958 roku o rzecznikach patentowych ${ }^{23}$ (dalej: u.r.p.1958). Uchwalona na fali zmian zapoczątkowanych buntem społecznym z października 1956 roku oraz szerszym procesem destalinizacji w obrębie obozu komunistycznego zapoczątkowała relatywnie krótki okres swoistej „restauracji” profesji rzecznika patentowego jako zawodu wolnego. Przy zachowaniu ogólnego schematu regulacji zasad jego wykonywania, obejmującego w szczególności zdefiniowanie jego przedmiotu, określenie wymogów warunkujących uzyskanie uprawnień zawodowych, oraz przy zachowaniu uprawnień decyzyjnych Prezesa Urzędu Patentowego w zakresie wpisu na listę rzeczników patentowych i wyraźnie zaakcentowanych przez ustawę uprawnień w zakresie nadzoru nad działalnością rzeczników patentowych ${ }^{24}$ nowa ustawa wprowadzała szereg rozwiązań prawnych nakierowanych na próbę umiejscowienia profesji rzecznika jako wolnego zawodu w ramach porządku prawnego „Państwa Ludowego”. Rzecznik patentowy wyraźne zobowiązany był do ochrony i umacniania porządku prawnego państwa ludowego i dochowania mu wierności — z drugiej strony jednak przestrzegać miał etyki zawodowej (nie urzędniczej jak poprzednio) w wykonywaniu profesji rzecznika patentowego ${ }^{25}$.

22 Zob. charakterystyka pracowniczych i niepracowniczych stosunków zatrudnienia T. Kuczyński, [w:] H. Szurgacz et al., Prawo pracy. Zarys wykładu, Warszawa 2016, s. 365 n.

23 Dz.U.1958.31.139 z dnia 6 czerwca $1958 \mathrm{r}$.

24 Zob. w szczególności art. 1-4 u.r.p.1958. Zgodnie z art. 18 ust. 1-2 u.r.p.1958 nadzór nad działalnością rzeczników patentowych sprawował Prezes Urzędu Patentowego, a Prezes Rady Ministrów ustalał zakres nadzoru, o którym mowa w ust. 1, oraz zasady i tryb jego wykonywania.

25 Zgodnie z art. 4 u.r.p.1958 rzecznik patentowy przed rozpoczęciem czynności zawodowych składał przed Prezesem Urzędu Patentowego przyrzeczenie o treści: „Przyrzekam uroczyście w mojej pracy rzecznika patentowego przyczyniać się do ochrony i umacniania porządku prawnego Państwa Ludowego, któremu wierności zawsze dochowam, obowiązki rzecznika patentowego wy- 
Fundamentalną zmianę myślenia o zawodzie rzecznika patentowego wyrażało wskazanie kancelarii rzeczniowskiej jako wyłącznej formy wykonywania zawodu oraz platformy organizacyjnej samodzielnego świadczenia właściwie udokumentowanych i odpłatnych usług zawodowych (art. 11-13 u.r.p.1958). Istotne znaczenie miały przepisy chroniące niezależność i obiektywizm zawodowy rzecznika patentowego oraz gwarantujące dostępność i poufność jego usług (art. 5 ust. 1-4, 7, 8, 9 u.r.p. 1958$)^{26}$. Za istotne dla wyodrębnienia statusu rzecznika patentowego jako zawodu wolnego należy uznać uregulowanie w tej ustawie zasad odpowiedzialności dyscyplinarnej ,za postępowanie sprzeczne z zasadami prawa bądź też za naruszenie swych obowiązków zawodowych" (art. 15-17 u.r.p.1958) ${ }^{27}$. Istotnym novum było powołanie zrzeszenia rzeczników patentowych jako swoistej ograniczonej formy ich samorządu zawodowego realizującego zadania określone generalnie przez ustawę jako: 1. ustalanie prawidłowych zasad wykonywania zawodu rzecznika patentowego, 2 . reprezentowanie ogółu rzeczników patentowych ${ }^{28}$.

pełniać gorliwie, sumiennie i zgodnie z przepisami prawa, dochować tajemnicy zawodowej, a w postępowaniu moim kierować się zasadami godności, uczciwości i sprawiedliwości społecznej”.

${ }^{26} \mathrm{~W}$ świetle przepisów z art. 5 ust. 1-4 u.r.p.1958 z zawodem rzecznika patentowego nie wolno było łączyć stanowiska w Urzędzie Patentowym, w wymiarze sprawiedliwości i w notariacie. Prezes Rady Ministrów mógł rozciągnąć zakaz określony w ust. 1 na innych pracowników państwowych oraz na żołnierzy zawodowych w służbie czynnej. Adwokat nie mógł być wpisany na listę rzeczników patentowych, dopóki pozostawał na liście adwokatów. Rzecznikowi patentowemu nie wolno było również objąć stanowiska lub podejmować się zajęcia kolidującego z wykonywaniem zawodu rzecznika patentowego. W świetle przepisu art. 7 u.r.p.1958 rzecznik patentowy nie mógł przyjąć zastępstwa lub udzielić pomocy, jeżeli zastępował stronę przeciwną lub udzielił jej pomocy w tej samej bądź związanej z nią sprawie, nie mógł również udzielić pomocy w sprawie, w której brał udział $\mathrm{z}$ ramienia organów administracji państwowej. $\mathrm{Z}$ kolei zgodnie $\mathrm{z}$ art. 8 u.r.p.1958 rzecznik patentowy był obowiązany zachować w tajemnicy wszystko, o czym dowiedział się z tytułu wykonywania zawodu rzecznika patentowego. Zgodnie zaś z art. 9 ust. 1-2 u.r.p.1958 rzecznik patentowy mógł odmówić udzielenia pomocy lub przyjęcia zastępstwa tylko z ważnych powodów. Wątpliwości co do udzielenia lub odmowy pomocy oraz przyjęcia zastępstwa rozstrzygać miało zrzeszenie rzeczników patentowych.

27 Za czyny objęte odpowiedzialnością dyscyplinarną rzecznika patentowego określoną w art. 15 u.r.p. 1958 wymierzane być miały kary dyscyplinarne. W świetle art. 16 u.r.p. 1958 karami dyscyplinarnymi były: 1 . upomnienie, 2 . nagana, 3 . zawieszenie w czynnościach zawodowych na okres od trzech miesięcy do dwóch lat, 4. skreślenie z listy rzeczników patentowych. W świetle zaś art. 17 ust. 1 u.r.p.1958 kary dyscyplinarne wymierzane być miały w pierwszej instancji przez Komisję Dyscyplinarną przy Urzędzie Patentowym, a w drugiej instancji — Odwoławczą Komisję Dyscyplinarną przy Prezesie Rady Ministrów.

28 Ustawa z dnia 22 maja 1958 r. o rzecznikach patentowych przewidywała przy tym nieliczne konkretne uprawnienia realizowane przez zrzeszenie: opiniowało ono decyzję Prezesa Urzędu Patentowego o wpisie na listę rzeczników patentowych (art. 3 ust. 2 u.r.p.1958) czy też rozstrzygało wątpliwości co do udzielenia lub odmowy pomocy oraz przyjęcia zastępstwa przez rzecznika patentowego (art. 9 ust. 2 u.r.p.1958). Co jednak należy podkreślić, samą organizację owego zrzeszenia rzeczników, jego szczegółowy zakres działania oraz zasady funkcjonowania określić miał Prezes Rady Ministrów w drodze rozporządzenia (art. 19 ust. 1-3 u.r.p.1958). 
Niestety po kilkuletnim okresie osobliwej z dzisiejszego punktu widzenia urzędowej kontestacji przepisów ustawy z dnia 22 maja 1958 roku o rzecznikach patentowych i swoistego faktycznego zawieszenia ich obowiązywania, najprawdopodobniej jako niepasujących do zmieniających się realiów politycznych i ustrojowych (odejście od „odwilży październikowej” po wydarzeniach 1956 roku), zawód rzecznika patentowego w formule dostosowanej do realiów scentralizowanej socjalistycznej gospodarki planowej powrócił od 1966 roku zredukowany w gruncie rzeczy do szczególnego, regulowanego prawem rodzaju pracy wykonywanej przez dysponujących uprawnieniami zawodowymi pracowników w rozumieniu prawa pracy. Byli oni ściśle podporządkowani kierownikom zatrudniających ich jednostek — tak zwanych uspołecznionych zakładów pracy ${ }^{29}$.

\section{Bibliografia}

Boć W., Status prawny notariusza, Wrocław 2010.

Borowicz J., Status prawny rzecznika patentowego zatrudnionego w ramach stosunku pracy, „Praca i Zabezpieczenie Społeczne" 1994, nr 7.

Borowicz J., Wykonywanie wolnego zawodu $w$ ramach stosunku pracy $w$ prawie polskim, Wrocław 2020.

Jacyszyn J., ,, Wolny zawód” - anachronizm czy istotne pojęcie prawne?, „Przegląd Prawa Handlowego" 2015, nr 11.

Jacyszyn J., Wolny zawód - mit czy rzeczywistość prawna, „Przegląd Prawa i Administracji” 100, 2015, $\mathrm{nr} 1$.

Jacyszyn J., Wykonywanie wolnych zawodów w Polsce, Warszawa 2004.

Słomski M., Historia rzecznictwa patentowego w Polsce, Kraków1997.

Szurgacz H., Kubot Z., Kuczyński T., Tomanek A., Prawo pracy. Zarys wykładu, Warszawa 2016. Wojtczak K., Zawód i jego prawna reglamentacja. Studium z zakresu materialnego prawa administracyjnego, Poznań 1999.

29 Zob. ustawa z dnia 21 kwietnia 1966 r. o rzecznikach patentowych, Dz.U.1966.14.86 z dnia 29 kwietnia 1966 r. Na ten temat zob. też M. Słomski, op. cit., s. 46 n., 58 n.; J. Borowicz, Wykonywanie..., s. 15. 